\title{
Magnetic and Restivity Investigation of Geologic Structures in the Basement Complex of Aran-Orin, Kwara-State, Nigeria.
}

'Muyiwa Adekunle Adeyanju ( $\square$ adeyanjumuyiwa97@gmail.com )

Anchor University Lagos

Oluwaseun Victoria Fatoye ( $\sim$ ofatoye@aul.edu.ng )

Anchor University Lagos

O.E Oyanameh

Anchor University Lagos

\section{Research Article}

Keywords: groundwater prospective, vertical electrical sounding (VES), resistivity, depth to basement, magnetic

Posted Date: September 29th, 2021

DOI: https://doi.org/10.21203/rs.3.rs-905217/v3

License: (c) (i) This work is licensed under a Creative Commons Attribution 4.0 International License. Read Full License 


\section{Abstract}

The study aims to integrate magnetic and vertical electrical sounding (VES) resistivity methods to determine groundwater prospective in part of Aran-orin Sheet 224. A total of three traverses were established in the study area for the vertical electrical sounding using the Schlumberger electrode configuration. A total of 17 VES points was established using the ABEM Terrameter SAS 1000C model with maximum half-current electrode spacing $(A B / 2)$ of $120 \mathrm{~m}$. A total of eight traverses were established for the magnetics survey with station intervals of $10 \mathrm{~m}$ and inter-profile spacing of $100 \mathrm{~m}$. The magnetic and VES data were qualitatively and quantitatively interpreted using IPI2WIN and OASIS MONTAJ package respectively. The geo-electric sections reveal a maximum of 3-4 layers beneath the sub-surface an overburden thickness ranges from $8.2 \mathrm{~m}$ to $64.9 \mathrm{~m}$ and the corresponding lithology inferred are topsoil, weathered Rock, fractured basement and fresh basement. The depth to basement using halfwidth method showed that the depth ranges from 8.4-56.04 m, which corresponds with the electrical survey.

\section{Introduction}

In hard rock terrains, groundwater potential mapping is relatively complex due to highly variable nature of the geological terrain (Kellgren 2002: Anbazhagan et al. 2011). Extensive hydrogeological investigations are required in basement complex terrains for proper understanding of groundwater conditions (Solomon and Quiel 2006; Balamurugan et al. 2008; Pradhan 2009).

The research was carried out in Aran-Orin sheet 224 South-western Nigeria. The mapped area falls under the basement complex rock terrain of Nigeria. The basement complex is one of the three major lithopetrological components that make up the geology of Nigeria (Rahaman 1976). The Nigerian basement complex forms a part of the Pan-African mobile belt and lies between the West African and Congo cratons and the Tuareg shield. Examples of rocks found in this area includes schists, granite quartzite and gneiss.

The study area is underlain by the rocks of the basement complex of South-Western Nigeria, which is of the Precambrian to Cambrian in age. It comprises of both gneiss-granite and meta-sediments which are mainly schist and quartzite. The area of interest is between latitudes $0804^{\prime} 59.35^{\prime \prime}$ and $0805^{\prime} 30^{\prime \prime} \mathrm{N}$ and longitudes $0505 \otimes 59.31^{\prime \prime}$ and $0505^{\prime} 13 \mathrm{E}$.

The geophysical survey was done to decipher the subsurface geology with one of the major point of interests on the fracture-controlled river of the area. The objectives of the research are to determine depths to fresh basement rocks using vertical electrical sounding method and ground magnetic profiling techniques.

\section{Location of the study area}


The area of study is Aran-Orin town in Irepolodun LGA, Kwara state, Nigeria. It is a border town located very close to Osun and Ekiti states to the south. The tropical rain forest city of Aran-Orin lies a few kilometers west of Omu-Aran. Other towns in close proximity are Arandun, Rore, Ipetu, Erin-mope, Ilale. (figure1.1).

Aran-Orin is located at 8km to Omu-aran in Kwara State, Nigeria. It lies within latitude 08 05区 30区 and 08

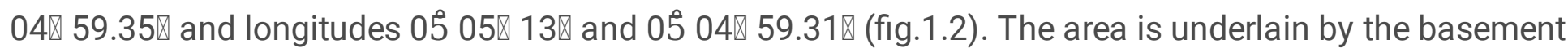
complex rock of the Precambrian and Cambrian ages (Rahaman, 1976; Oyegun, 1983) undifferentiated meta-sediments are found in numerous large patches of the state like Oke-Ode. Oke Onigbin, Omu-Aran while the older granites arc also found in numerous patches in parts of Moro, Asa and Ifelodun Local Government Areas. Quartzites are found in North Western part of Ilorin (Oyegun, 1983).

\section{Materials And Method}

\section{Electrical Method}

The aim of the study was to show basement rock topography in Aran-Orin Area. The objectives were to determine depths to fresh basement rocks using vertical electrical sounding method and ground magnetic profiling techniques. The vertical electrical soundings (VES) were made in 17 (seventeen) stations as shown in figure 2.1. The data were interpreted to give geo-electric layers and especially thickness of the overburden materials above the fresh basement rocks. An isopach map of depth to basement rock was drawn.

\section{Magnetic Method}

The aim of a magnetic survey is to investigate subsurface geology on the basis of anomalies in earth's magnetic field resulting from the magnetic properties of the underlying rocks. Although most rock forming minerals are effectively non-magnetic. Certain rock types contain sufficient magnetic minerals to produce significant magnetic anomalies (Horsfall K.R 1997).

Magnetic surveys can be performed on land, on sea (sea borne) and in the air (air borne). Consequently, the technique is widely employed, and the speed of operation of airborne surveys makes the method very attractive, this method will be discussed in details in subsequent section. Magnetics survey is a geophysical survey technique that exploits the considerable differences in the magnetic properties of minerals with the ultimate objective of characterizing the Earth's sub-surface. The technique requires the acquisition (Horsfall, 1997) of measurements of the amplitude of the magnetic field at discrete points along survey lines distributed regularly throughout the area of interest.

The magnetic field whose amplitude is measured is the vector sum of:

i. The Earth's Main field. 
ii. An Induced field caused by magnetic induction in magnetically susceptible earth materials polarized by the main field.

iii. A field caused by remanent magnetism of earth materials.

iv. Other less significant fields caused by solar, atmospheric and cultural influences

(Telford W. et al., 1976.

Aeromagnetic surveying is rapid and cost-effective, typically costing some $40 \%$ less per line kilometer than a ground survey. Vast areas can be surveyed rapidly without the cost of sending a field party into the survey area and data can be obtained from areas inaccessible to ground survey. The vast majority of magnetic surveys are carried out in the air, with the sensor towed in a housing known as a 'bird' to remove the instrument from the magnetic effects of the aircraft or fixed in a 'stinger' in the tail of the aircraft, in which case inboard coil installations compensate for the aircraft's magnetic field. The magnetic field is usually measured with a total field magnetometer. The most common instrument in use today is the caesium-vapour magnetometer. Observations are made at regular intervals along a series of flight lines of constant azimuth and spacing. Observations are similarly made along the lines oriented perpendicular to the traverse lines. Tie lines are necessary to assist in the removal of temporal variations in the main field. Tie lines are usually spaced about ten times further apart than traverse lines (Brodie C. Ross, 2002). Various corrections are necessary to be done on the acquired data for accurate geophysical extrapolations to be made.

\section{Results And Discussion}

\section{Electrical Resistivity Data}

The interpretation of geophysical data involves expressing the information obtained from the surface measurement into geological section/form, from which both qualitative and quantitative deductions can be made. The data reveal generally three geo-electric layers, top layer with resistivity value of $A B / 2=1 \mathrm{~m}$ ranging between 15.875 and $2807 \mathrm{ohm}-\mathrm{m}$. The middle layer has resistivity value of $A B / 2=20 \mathrm{~m}$ ranging between 104.2 and 1146 ohm-m the third geo-electric layer has resistivity values ranging between 185.6 and $70755 \mathrm{ohm}-\mathrm{m}$. In this research IP12Win is used in Vertical electrical sounding interpretation while SURFER 10 is used for the map interpretations.

The characteristic VES curves derived from the vertical electrical soundings at 17 points along two profiles (A and B) were characterized according to their signatures, which mirrors the lithological layering of the subsurface in the area. Sample field curves at sounding locations across the study area are shown in figures 3.1 to 3.4 (Resistivity curve for VES 3, VES 4, VES 5, VES 6). In each of these diagrams both the variations of apparent resistivity with electrode spacing as well as the modeled layer resistivity versus depth are plotted. The names and the number of occurrences in parenthesis are: $\mathrm{A}(1), \mathrm{AH}(1), \mathrm{K}(4), \mathrm{KH}$ (4), KHA (1), KQ (1), H (4), QH (1) curve types. KH, KHA and H curves are predominant amongst all other 
curves present. Six lithological layers were identified which are the Topsoil, laterite, clay, weathered rock, fractured basement, and fresh basement.

Based on the available geological information, the known resistivity values of some rocks used as a standard in the geological interpretation (Table 3.1) were used to identify the rock units to consist of the Topsoil, Laterite, clay, weathered Rock, fractured basement and fresh basement.

Table 3.1 Resistivity values of rock materials interpreted from the data.

\begin{tabular}{|l|l|}
\hline No. Rock types & Resistivity range $(\mathbf{o h m}-\mathbf{m})$ \\
\hline 1. Top soil & $5.78-123.53$ \\
\hline 2. Laterite & $127.7-541.21$ \\
\hline 3. clay & $45.4-113$ \\
\hline 4. Weathered rock & $280-619.76$ \\
\hline 5. Fractured basement & $399-815$ \\
\hline 6. Fresh basement & $564-1961$ \\
\hline
\end{tabular}

\section{Overburden Isopach Map}

The VES-derived isopach map enabled estimation of possible overburden thickness within the study area. The established depths to the bedrock beneath all the VES stations occupied were plotted and contoured on an isopach map of the overburden. The overburden thickness in the study area varies from $8.2 \mathrm{~m}$ to $64.9 \mathrm{~m}$. This was done to enable a general view of the depth to basement in the surveyed area. Areas with thin overburden correspond to shallow depths of weathering, while areas with thick overburden correspond to those with deep depths of weathering. From the interpretations and maps, VES2, VES3, VES9, VES15, VES5, VES12, VES16 are points that has thick overburden (within the range of $30 \mathrm{~m}-120 \mathrm{~m}$ ). The overburden is assumed to include the topsoil, the lateritic horizon, clay and weathered/fractured rocks. The isopach map is shown in the figure 3.4 and 3.5.

Table 3.2 Summary of the thickness of overburden. 


\begin{tabular}{|l|l|}
\hline VES Stations & Thickness of the overburden $(\mathbf{m})$ \\
\hline Ves1 & 23.9 \\
\hline Ves2 & 57.1 \\
\hline Ves3 & 64.9 \\
\hline Ves4 & 31.5 \\
\hline Ves5 & 36 \\
\hline Ves6 & 33.2 \\
\hline Ves7 & 18.8 \\
\hline Ves8 & 20 \\
\hline Ves9 & 8.06 \\
\hline Ves10 & 8.2 \\
\hline
\end{tabular}

\section{Interpretation of Ground Magnetic Data}

This study focuses on the subsurface geological structures based on the quantitative interpretations of the ground magnetic data. The data acquisition technique requires measurements of the magnetic intensities which were made at regular interval $10 \mathrm{~m}$ along eight (8) traverses distributed within the area. The ground magnetic study of this area was undertaken through the following processes: measurements of magnetic variations using the portable proton precession magnetometer and GPS were used to measure the longitude, Latitude and elevation along the profiles. A total of eight (8) magnetic profiles were established across the study area. The magnetic data were corrected for the diurnal Magnetic variations in order to obtain the residual magnetic field at grid cross points. The corrected magnetic data were plotted against distance to obtain magnetic profile with the aid of Excel software. This oldest form of presenting magnetic data has advantage of being able to show detail that cannot be shown in gridbased presentations. The contour maps, Total Magnetic Intensity (TMI) map and 3D surface maps and maps for the survey area were generated to image the subsurface structures. The reduced magnetic profiles (Baranov and Naudy, 1964) were interpreted using the Half-width rule method to determine the approximate depth to the magnetic source. The magnetic contour map of the area is shown in figure 3.6.

The total magnetic field map of the study area Aran-Orin (sheet 224), Nigeria after IGRF removal of $33,000 \mathrm{nT}$ is displayed in (figure3.10). The map is produced in color aggregate, with pink to red color depicting high magnetic anomalies while green to blue depicts low magnetic anomalies. The Total Magnetic Intensity map of the study area exhibits both positive and negative anomalies, with many structures trending mainly in NE-SW directions, alongside minor anomalies. The upper part of the area is predominantly of positive anomaly (high magnetic intensity) and a magnetic low intensity trend suspected to be fracture can be seen cutting across in the NE-SW direction while the middle portion is averagely positive (medium to high magnetic intensity anomalies). The lower part of the study area is also predominantly characterized by high magnetic intensity. However, both upper (NE, SW trend) and lower part of the study area are illustrating shallow depth to basement rocks or crystalline rocks. 
Magnetic lows trend in upper portion of the study area is suspected to be fracture zone with high water saturation while other magnetic lows in other portions of the study area suspected to be weathered terrain probably saturated with water.

\section{Regional and Residual Correction of Ground Magnetic Data}

The regional and residual field are respectively presented in figures 3.8 ( $a$ and $b$ ). Trends are the general direction in which the contour lines tend to have in a particular area of the map. The regional field in the study area (figure) which is obtained from the computed IGRF of 2005 epoch has a regional trend of NWSE. similar trends were observed by Ajakaiye and Burke (1972), which is attributed to long period of marked thermos-tectonic subsidence with pan African rift of cretaceous basement rocks.

The regional trends or simply regionals as shown on the map has contour interval of $5 \mathrm{nT}$. The difference between the measured or the observed field data and the regional field data gives the residual field data. The residual obtained consists of positive values ranging from $195.4 \mathrm{nT}$ to $438.4 \mathrm{nT}$ and the results from a relatively high magnetic anomaly in the study area.

\section{Half -Width Rule Method for Basement Depth Estimation}

The quantitative interpretation involved the use of half-width of the amplitude method Figure 3.12 for the estimation of overburden thickness Folami, (1992) and Alagbe et al. (2010). The estimated magnetic depths to the centre of the anomaly along each traverse were determine.

\section{Half Width Rule Structural Expressions}

For sphere (dipoles)

\section{$Z=2 X 1 / 2$}

For long horizontal cylinder (lines of dipoles)

\section{$Z=1.75 \times 1 / 2$}

For thin vertical cylinder (monopole)

\section{$Z=1.3 \times 1 / 2$}

For vertical thin sheet (lines of monopoles)

$Z=X 1 / 2$

$Z=2 X 1 / 2$

where $\mathbf{X} \mathbf{1 / 2}$ is the width of the anomaly at half peak or amplitude.

$Z$ = the depth to the centre of anomaly source. 
The magnetic profiles of the study area were generated. The results of estimated depth of the magnetic basement using the Half width rule ranges from $8.4 \mathrm{~m}$ to $56.04 \mathrm{~m}$, with the depth range on each profile shown in the table below, with the depth range on each profile shown in the table 3.4 below.

Table 3.4 Summary of depth range across each profile.

\begin{tabular}{|c|c|}
\hline Profile & Depth to basement Range (m) \\
\hline Profile 1 & $23.07-46.1$ \\
\hline Profile 2 & $18.10-56.04$ \\
\hline Profile 3 & $16.48-29.67$ \\
\hline Profile 4 & $24.73-37.90$ \\
\hline Profile 5 & 11.54 \\
\hline Profile 6 & $8.24-42.85$ \\
\hline Profile 7 & $22.25-46.15$ \\
\hline Profile 8 & $23.07-42.8$ \\
\hline
\end{tabular}

\section{Summary Of Findings}

Geo-electric and geomagnetic methods were used in mapping depth to basement of Aran-Orin sheet 224SW. The interpreted results of the 17 VES data points revealed 3 lithological layers to 6 lithological layers with depth to basement ranging from 8.06 to 64.9 , while 8 profiles were surveyed for the ground magnetics and a total of 345 data points were interpreted into depths using the half-width method. On the average, the depth to basement ranged between $23.07 \mathrm{~m}-46.1 \mathrm{~m}$ on profile $1,18.10 \mathrm{~m}-56.04 \mathrm{~m}$ on profile $2,16.48-29.67$ on profile $3,24.73 \mathrm{~m}-37.90 \mathrm{~m}$ on profile $4,11.54$ on profile $5,8.24-42.85$ on profile $6,22.25$ 46.15 on profile $7,23.07-42.86$ 0n profile 8 respectively. The depth to basement in the study area ranges between $8.24 \mathrm{~m}-56.04 \mathrm{~m}$ for the ground magnetics method. The essence of using both methods is to help complement the two methods and compare both results.

\section{Conclusion}

The results and interpretation of this research work has been compared and therefore shows correspondence between the electrical resistivity and magnetics method in delineation of depths to the basement rocks in the study area.

This study also revealed that the half-width rule method for depth estimation can be successfully used in estimation of depth to a magnetic source, the simplicity of the method makes it a very valuable tool in estimating the depth to basement. The method is much more time effective compared to other methods. 


\section{Declarations}

\section{CONFLICTS OF INTEREST}

The authors declare no conflict of interest.

\section{Funding Statement}

No funding, grant or other financial support was received.

\section{References}

Adelana et al, (2008). An Overview of Geology and Hydrogeology of Nigeria

Ajakaiye, D.E. and Burke,K.E. (1972). Bouguer gravity map of Nigeria.Tectonophysics

16,103

Alagbe 0.A., Sunmonu L.A. and Adabanija M.A. (2010). Ground magnetic Study on the Groundwater accumulation of Oke-Ogba area using ground magnetic survey. J. Appl.Sci. Environ. Manage. 14(4): 25-30.

Bala AE, Ike EC (2001). The aquifer of the crystalline basement rocks in Gusan area, North western Nigeria. J. Min. Geol., 37: 177-184

Johns.Brodie, R. C. (2002). Airborne and Ground Magneticss (vol. ACT 2601) Geoscience Australia P O Box 378, Camberra.

Kearey, P., M. B., \& I. H. (2002). An introduction to Geophysical Exploration. Blackwell edition.

Lowrie, W., (1997). Fundamentals of Geophysics, Cambridge University press, UK, pp.120 160.

Lowrie, W., (2007) Fundamentals of Geophysics, (vol.2nd edition). Zurich: Swiss Fedral University

Milsom,J., \& A. E. (2011). Field Geophysics (Vol 4). Wiley and Sons Ltd., Publication.

Mondal, S.K., Sastry, R.G., Pachauri, A.K., Gautam, P.K., (2008). High resolution 2D electrical resistivity tomography to characterize active Naitwar Bazar landslide, Garhwal Himalaya, India. Curr. Sci. 94 (7), 871-875.

Obaje NG (2009). Geology and mineral resources of Nigeria. Springer Dordrecht Heidelberg London New York, 221pp. http://dx.doi.org/10.1007/978-3-540-92685-6 Oboh-lkuenobe, F.E; Obi, C.G and Jaramillo, C.A. (2005). Lithofacies, palynofacie and sequence stratigraphy of Palaeogene strata in Southeastern Nigeria. Journal of African Earth Sciences, 41:79-101. 
Olasehinde, P.I (2010). The groundwaters of Nigeria: A solution to sustainable national water needs. Inaugural Lecture Series 17, Federal University of Technology, Minna, Nigeria.

Olorunfemi, M.O., Ojo, J.S. and Akintunde, O.M. (1999): Hydrogeophysical evaluation of the groundwater potential of Akure Metropolis, Southwestern Nigeria. Journal of Mining and Geology, 35(2): 207-228.

\section{Figures}

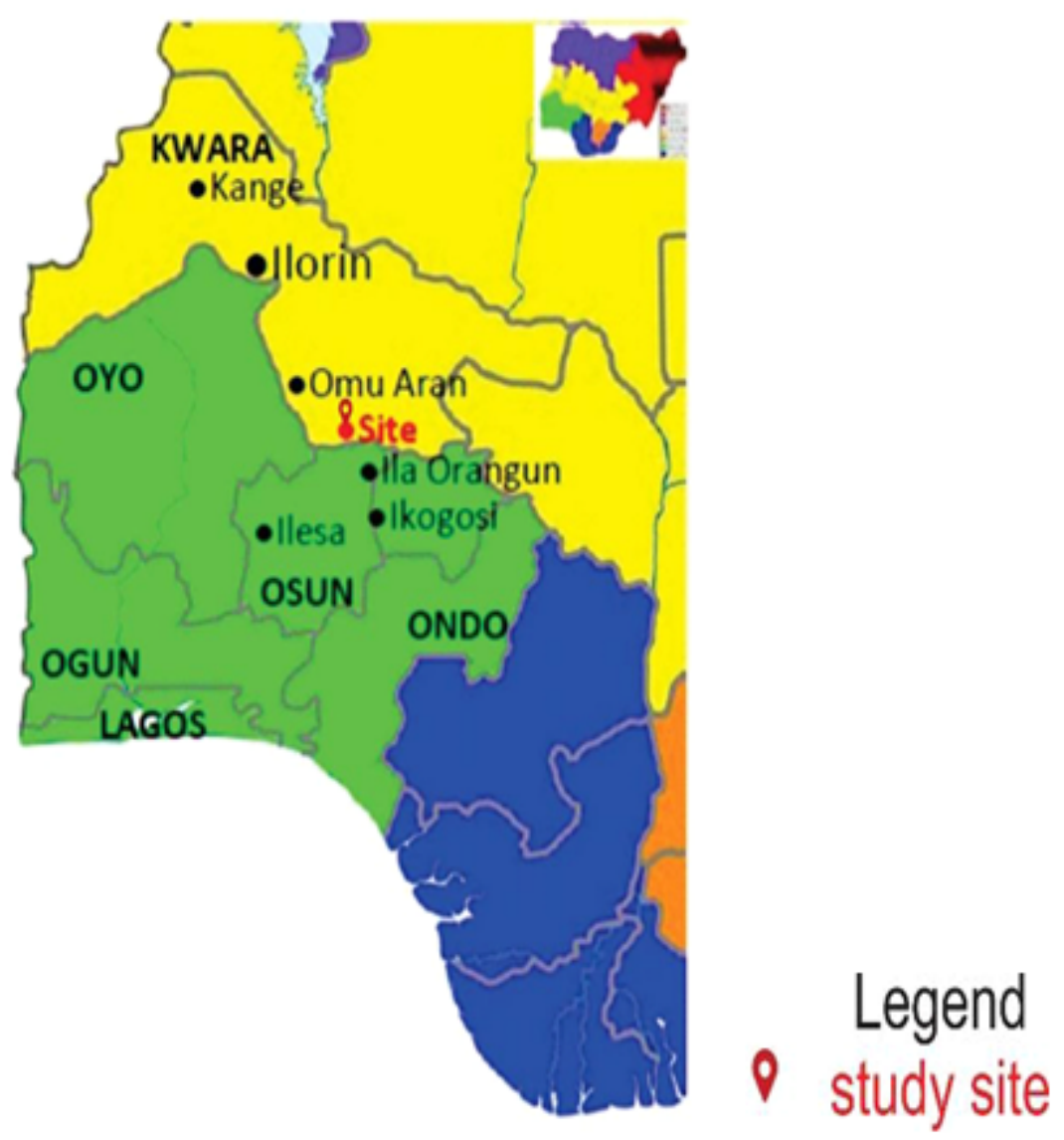

\section{Figure 1}

Figure 1.1 location of the surveyed site indicated on the political map of Western Nigeria. 


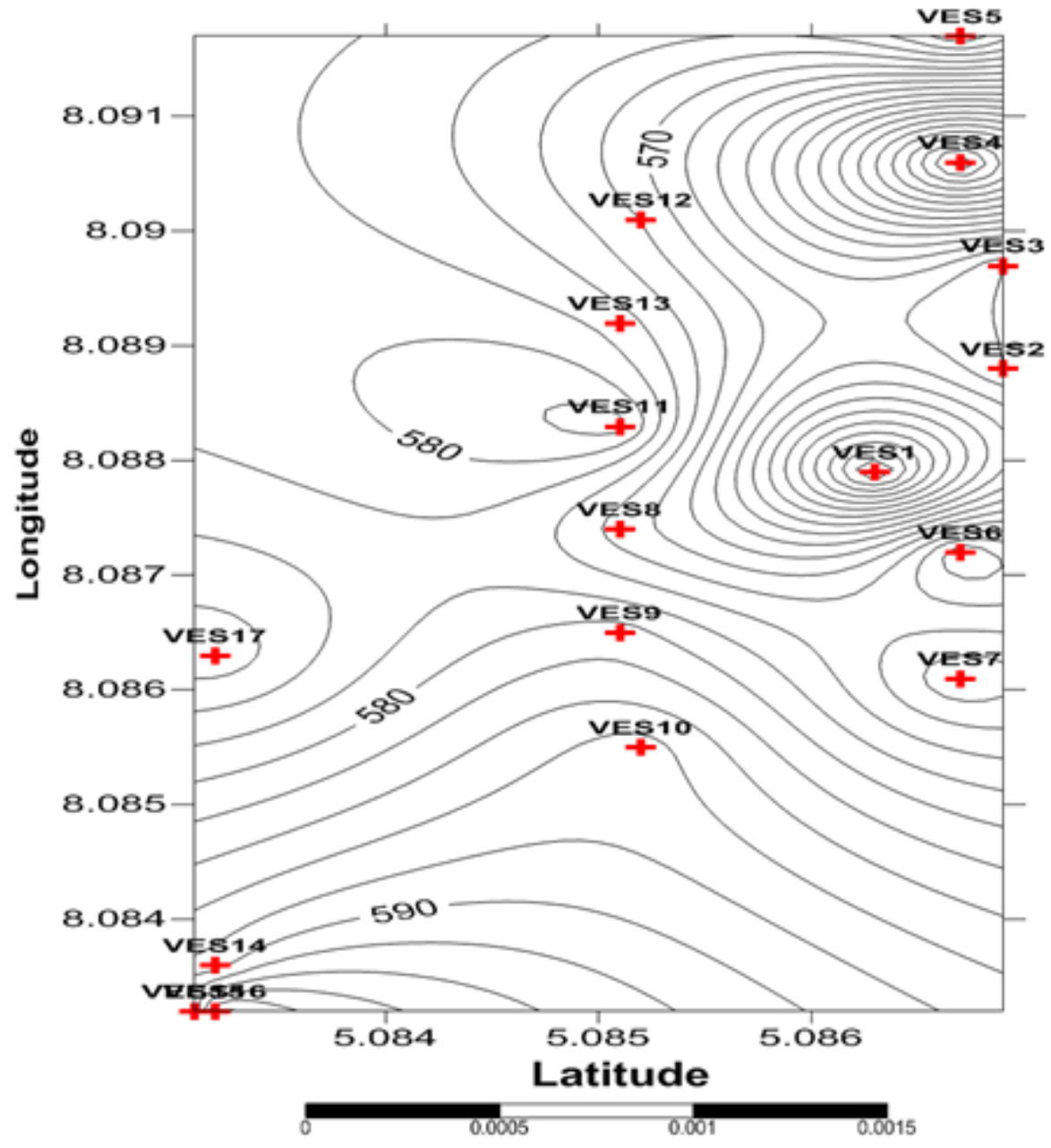

Figure 2

Figure 1.2 Topographic Map of the Study Area showing the VES Stations. 


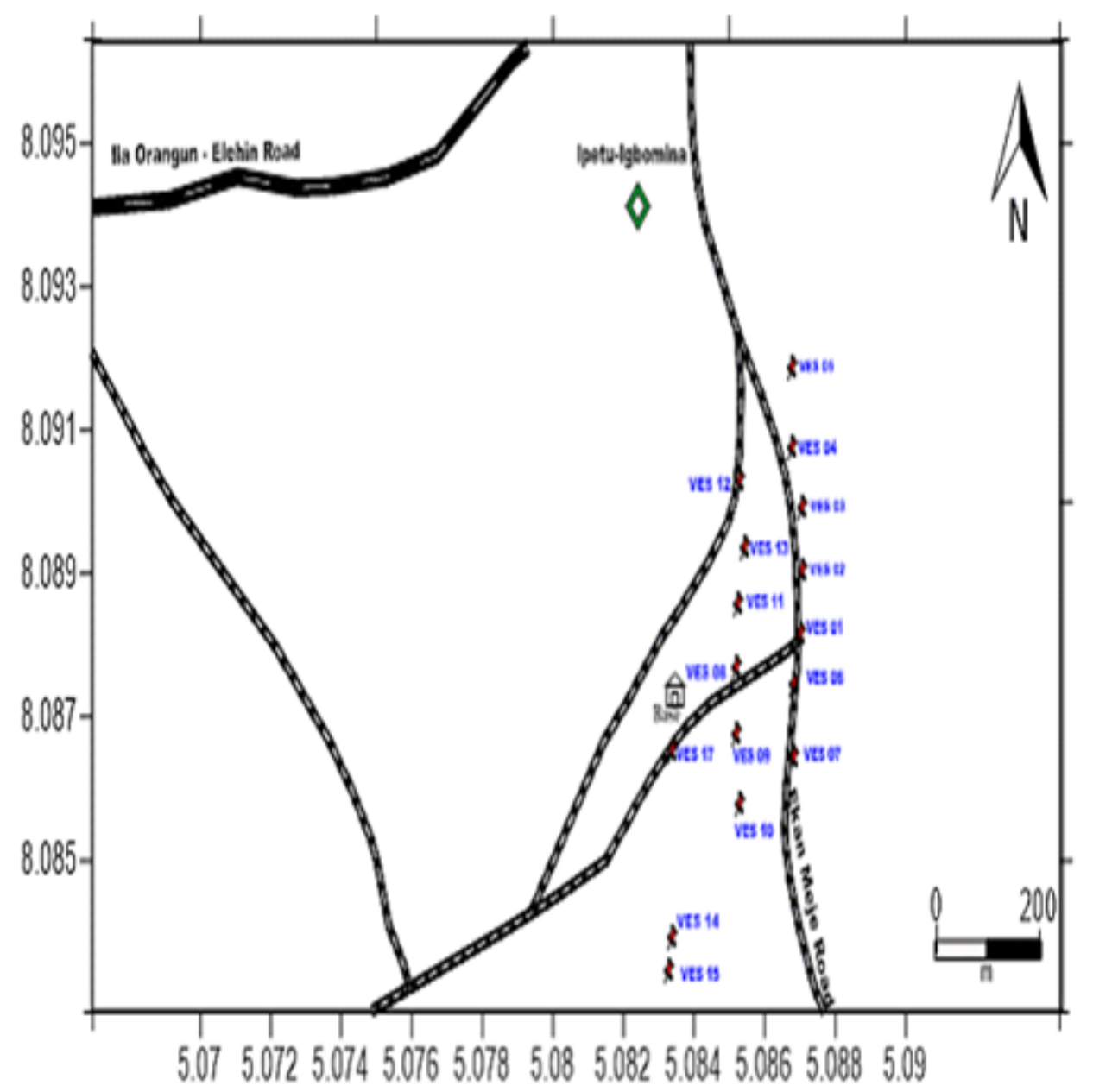

Figure 3

Figure 2.1 Base map of the study Area showing the VES profiles.

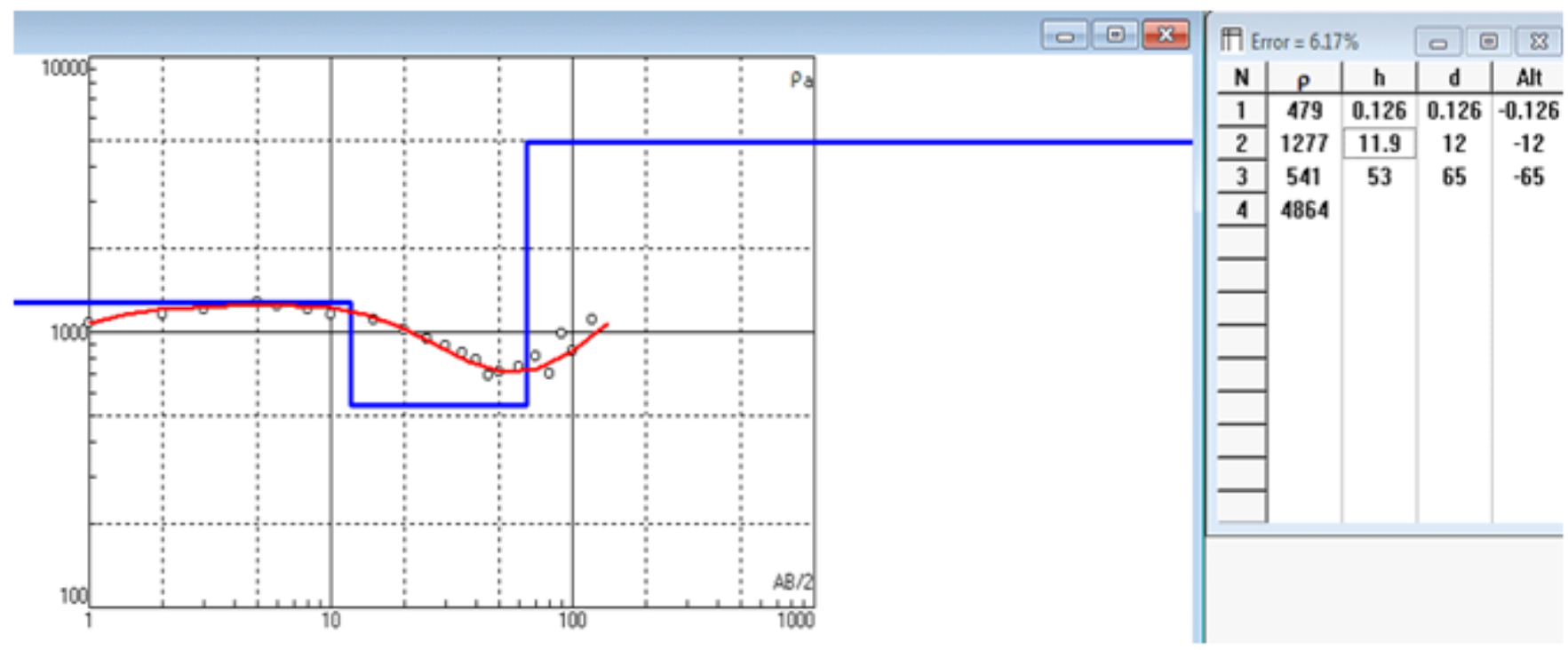

Figure 4 
Figure 3.1: Resistivity curve for VES 3

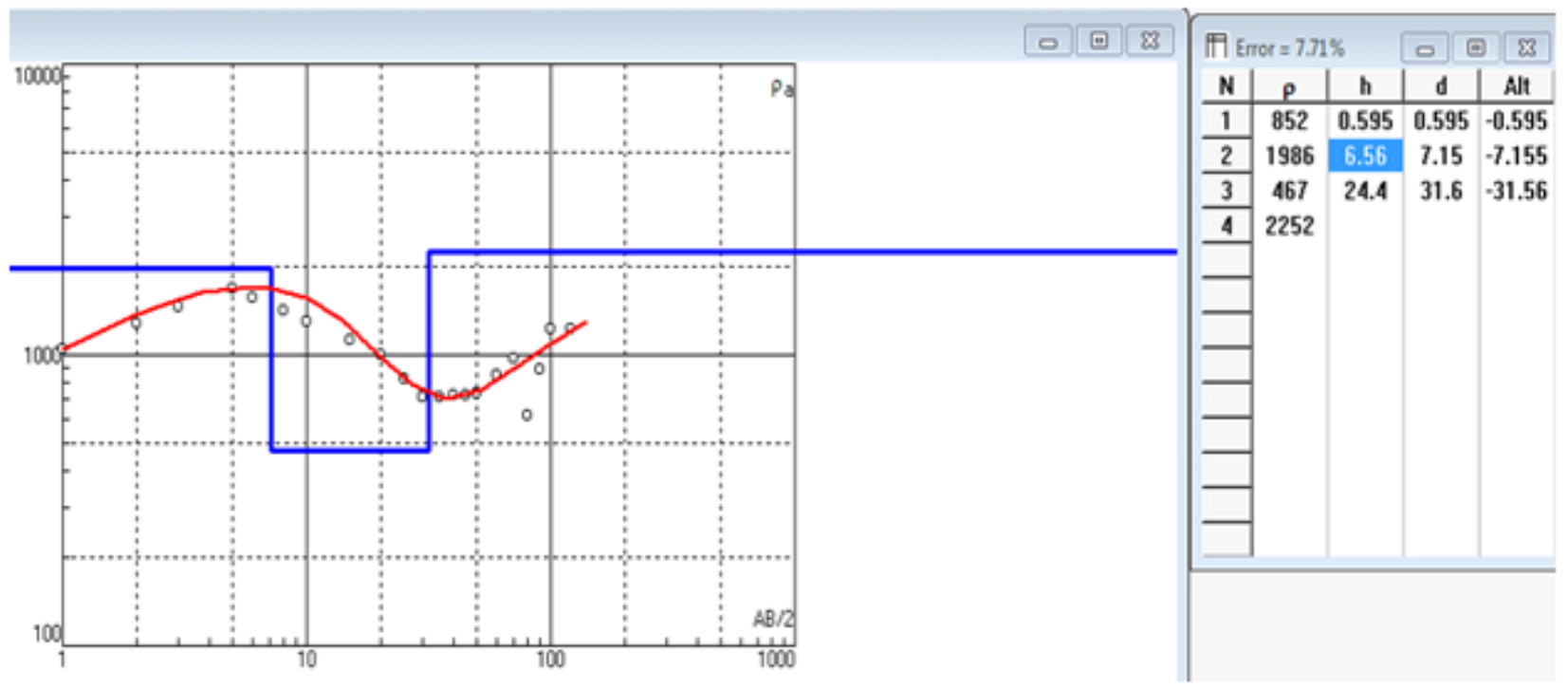

Figure 5

Figure 3.2: Resistivity curve for VES 4

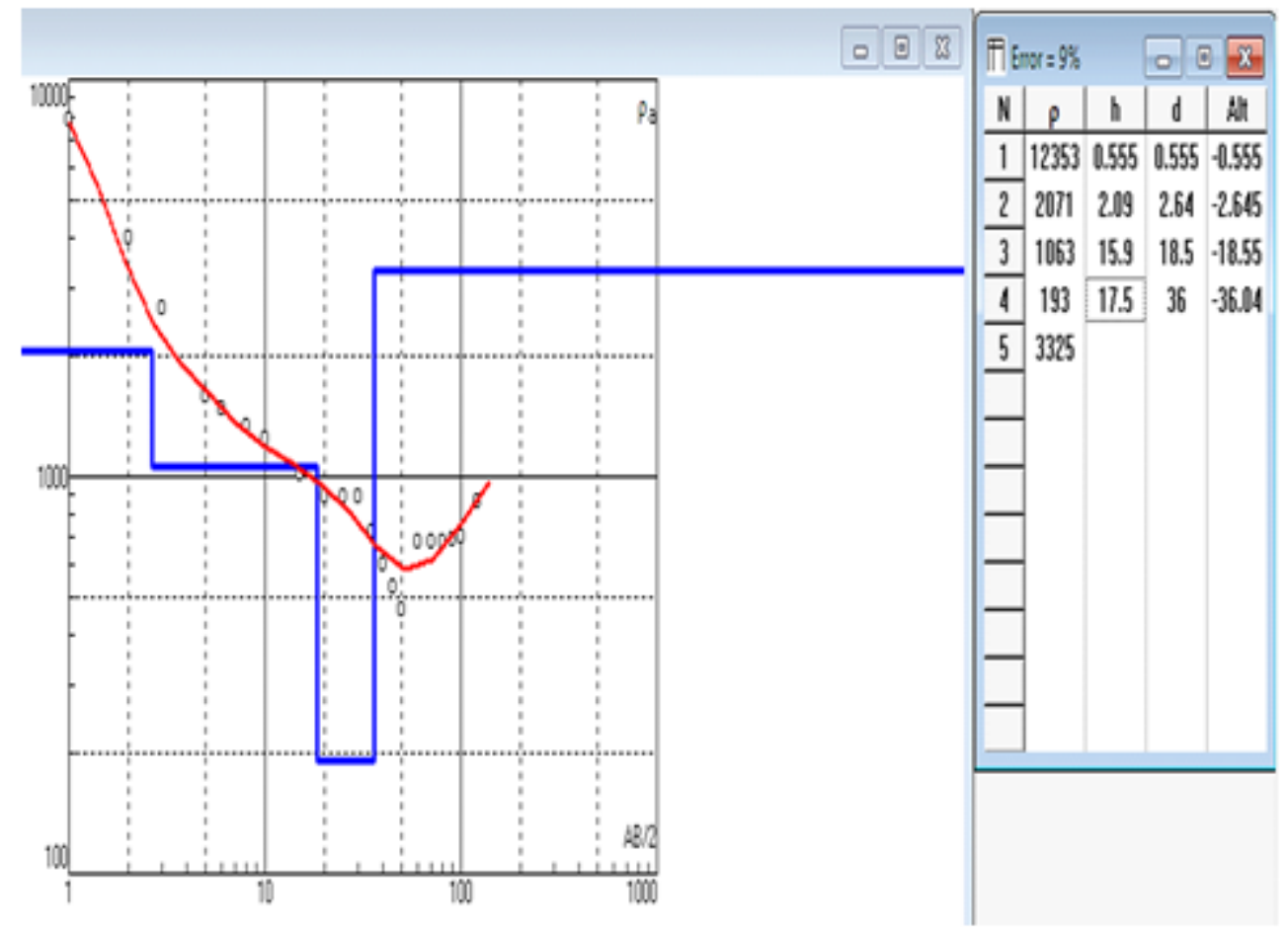

Figure 6

Figure 3.3 Resistivity curve of VES 5 


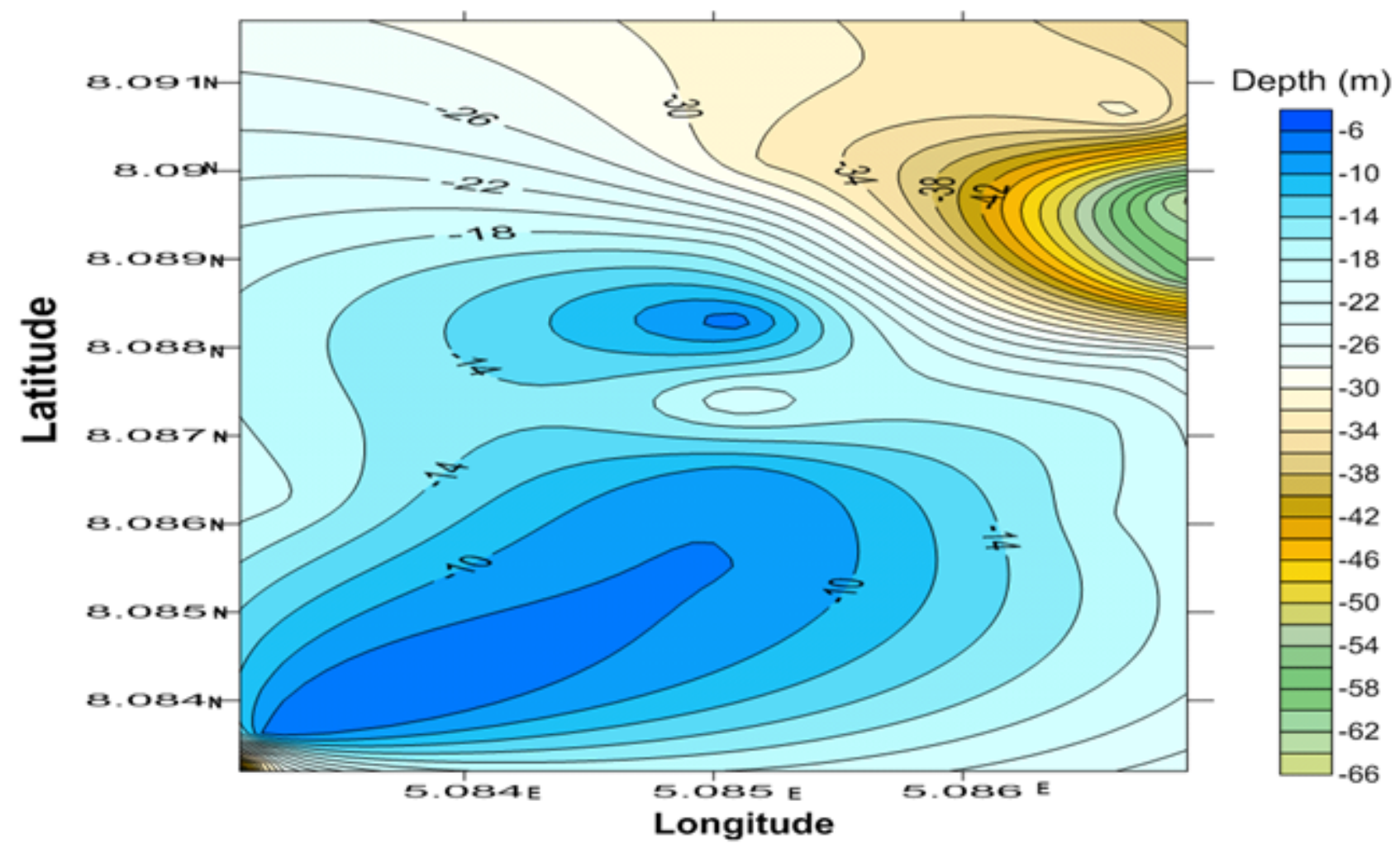

Figure 7

Figure 3.4 Contour map of overburden at Aran-Orin

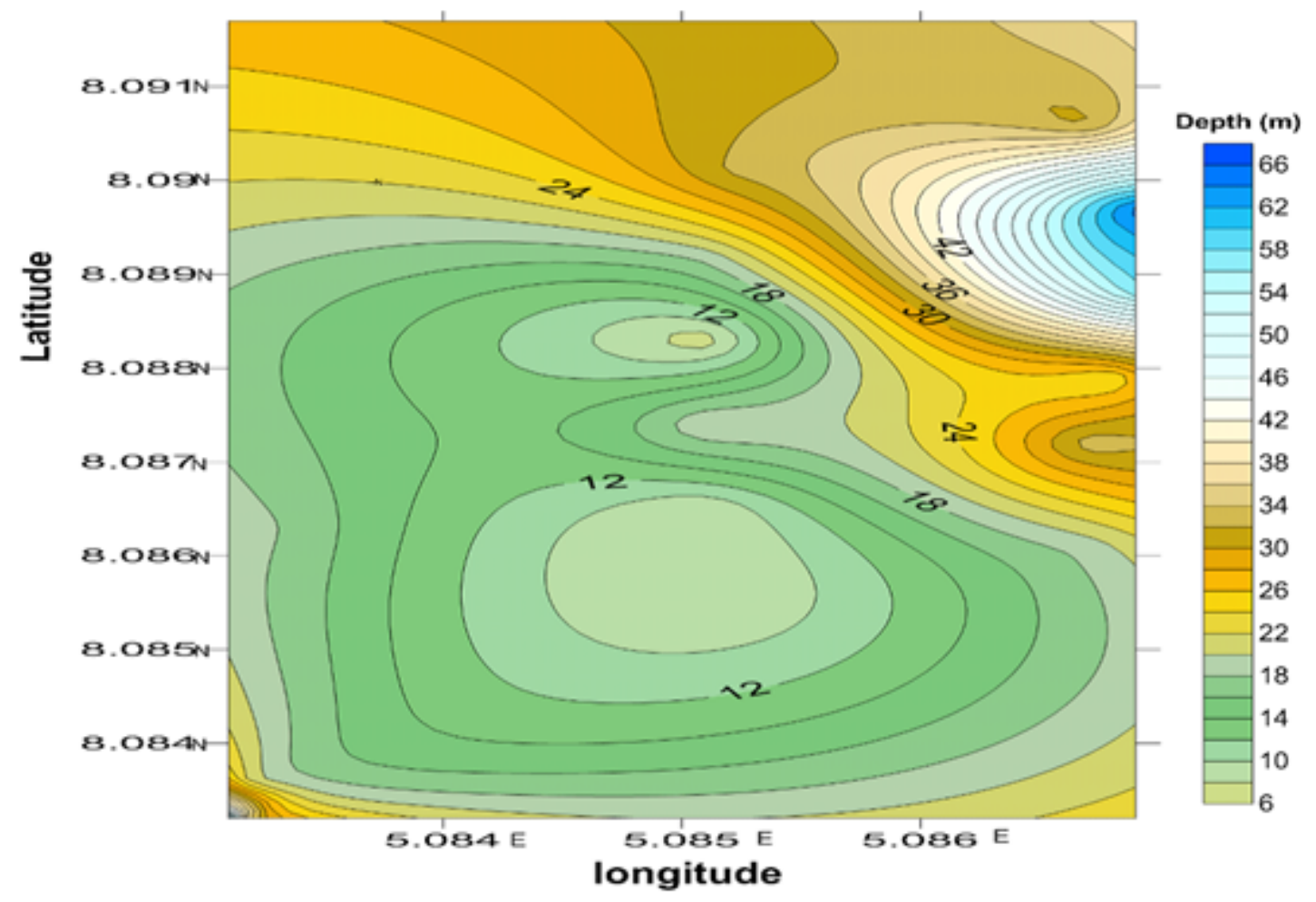


Figure 8

Figure 3.5 contour map of the basement

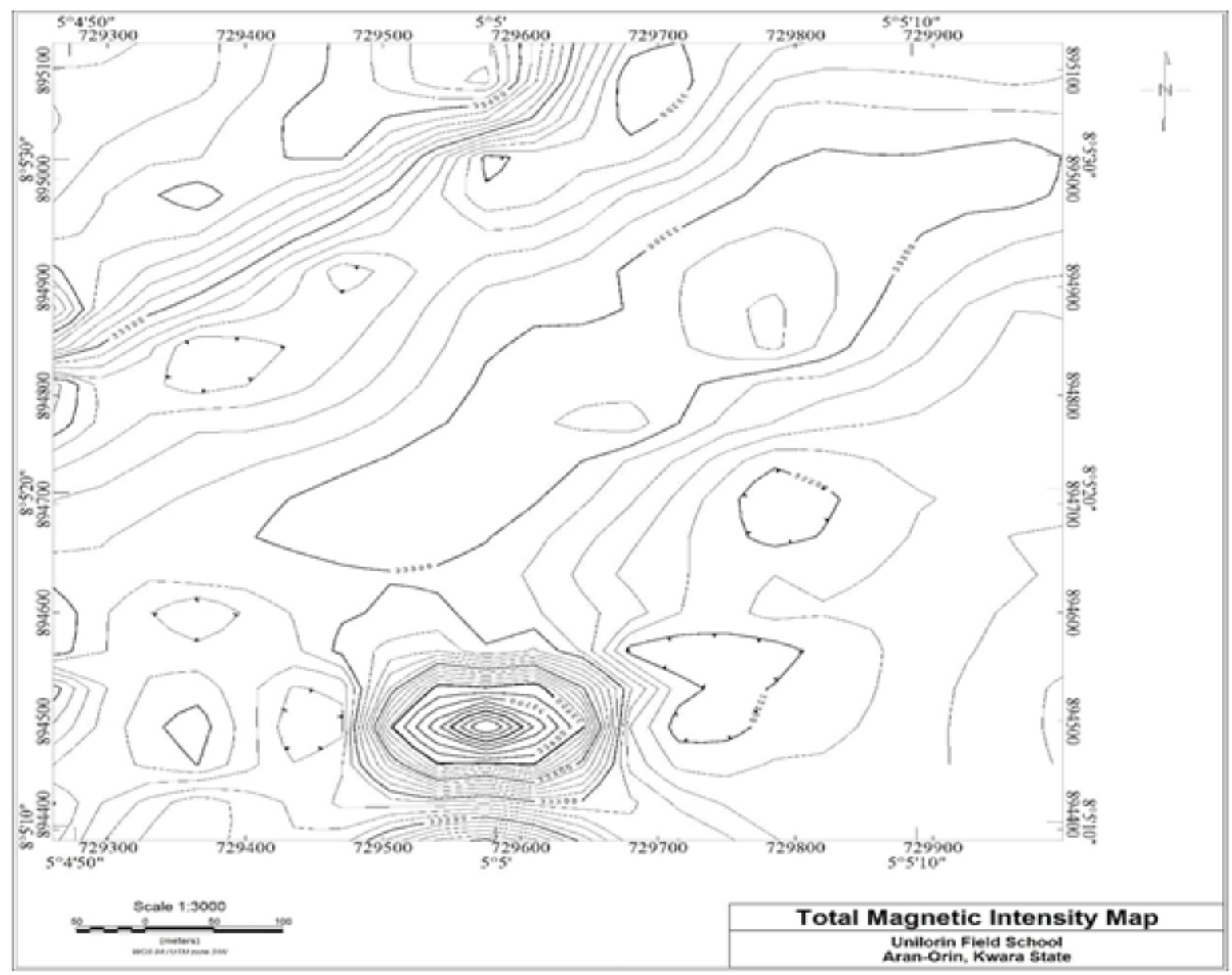

\section{Figure 9}

Figure 3.6: Total Magnetic Intensity Magnetics Contour Map of Aran-Orin area. 


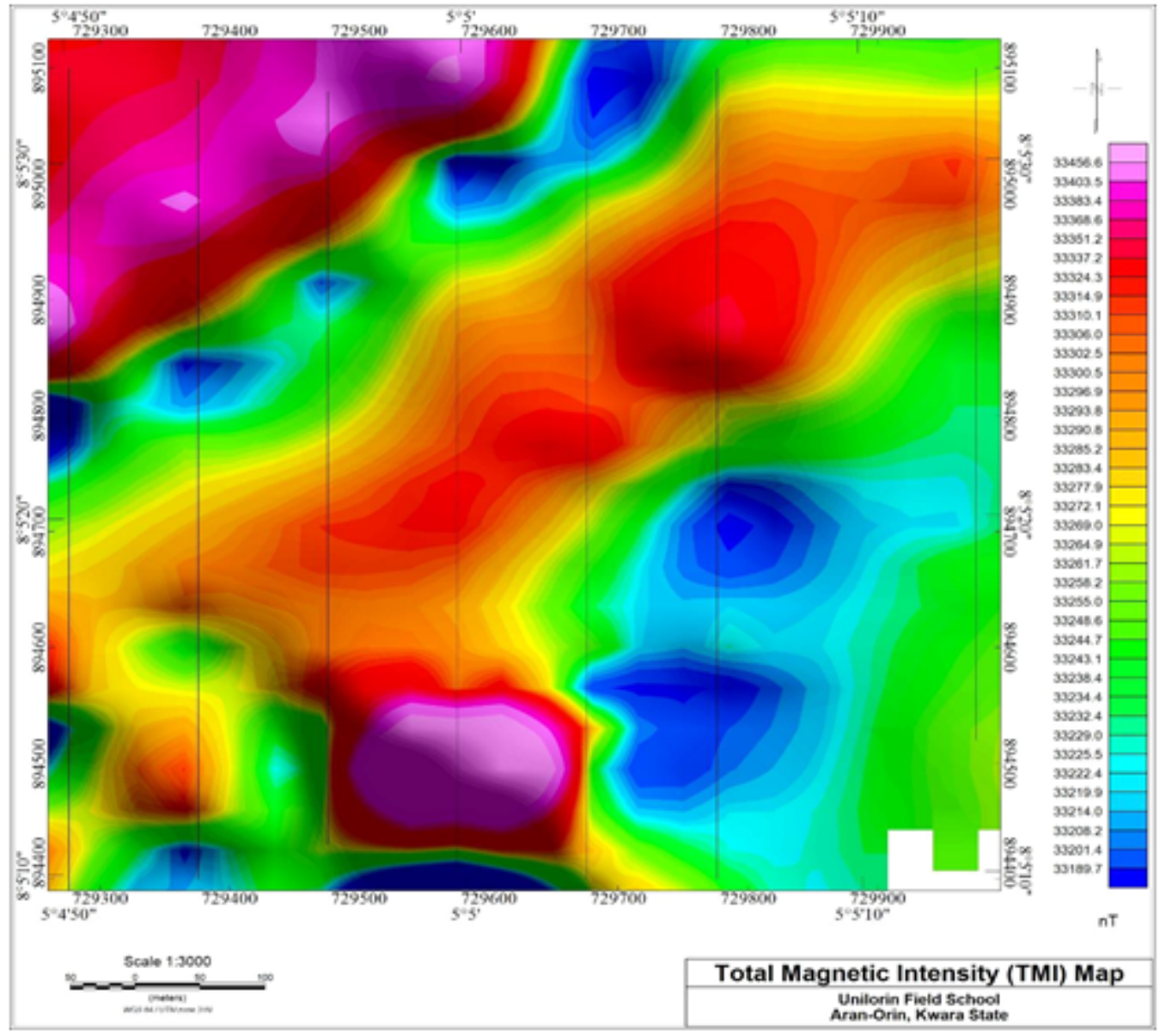

Figure 10

Figure 3.7: Colored Aran-Orin Ground Magnetic Map.

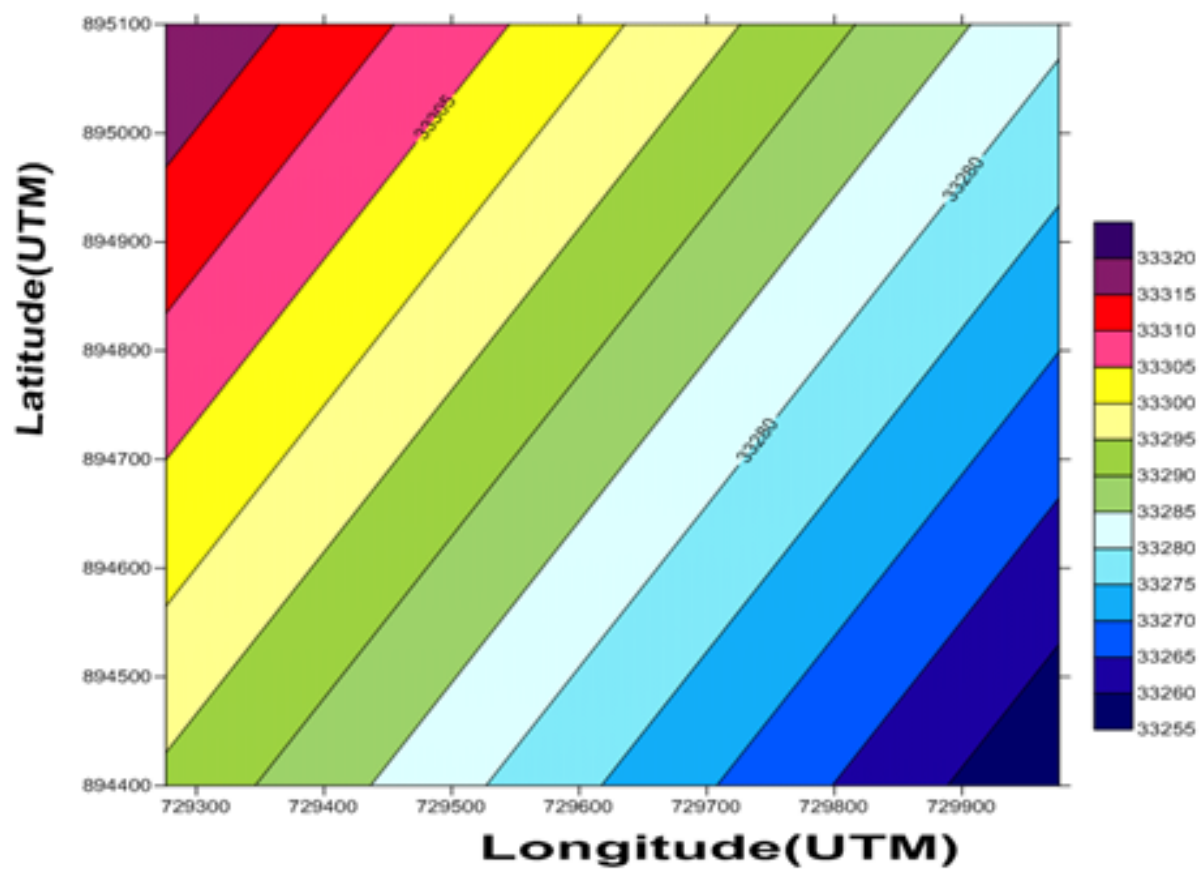




\section{Figure 11}

Figure 3.8a: Regional Map of the Study Area.

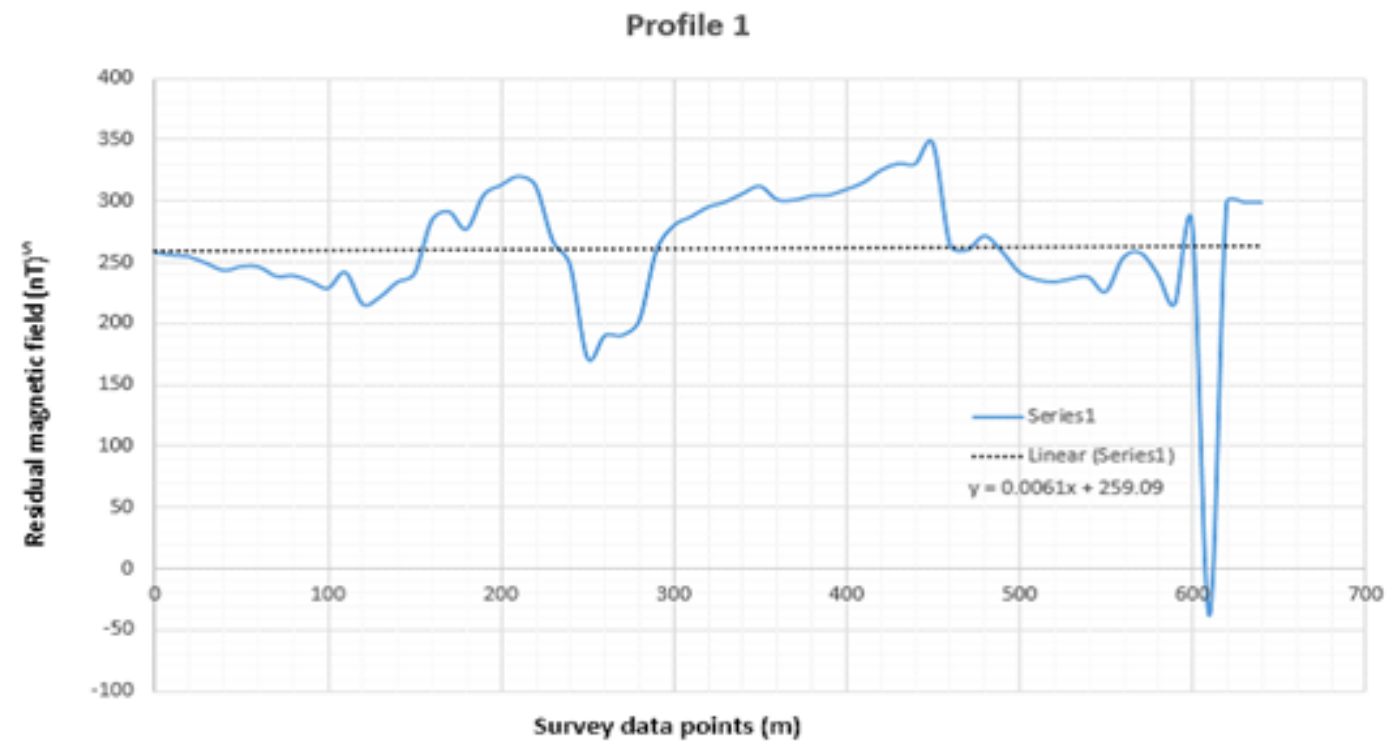

Figure 12

Figure 3.8b: A magnetic residual graph of profile 1 . 